\title{
Inventory of skin smear practices in 6 leprosy control programmes in Nigeria
}

\author{
NIYI AWOFESO \\ National Tuberculosis and Leprosy Training Centre, P.M.B. 1089, \\ Zaria, Kaduna State, Nigeria
}

Accepted for publication 6 November 1992

Summary A study of slit skin smear (SSS) examination practices in 6 Nigerian Leprosy Control Programmes was undertaken to assess the quality of smearing, staining and reading. Results indicated that the standard of SSS practices fall below the ideal. There is a great need for training as well as supervision and support of laboratory staff if this deplorable situation is to be improved.

\section{Introduction}

One of the cardinal signs for the diagnosis of leprosy is the demonstration of Mycobacterium leprae in slit skin smear (SSS). In some patients the demonstration of this causative organism provides the only proof of the diagnosis of leprosy. For differentiating between the 2 main classes of leprosy, i.e. paucibacillary and multibacillary, determining the treatment regimen, the assessment of SSS is often taken as the final arbiter. In many leprosy-endemic countries there is a severe shortage of laboratory staff skilled in the processing of SSS.

In Nigeria, with about 156,000 registered leprosy cases, ${ }^{1}$ leprosy is still an important public health problem and in view of the relevance of reliable SSS for the confirmation of diagnosis and classification, ${ }^{2}$ decisions on the duration of treatment and the diagnosis of multibacillary relapse, ${ }^{3}$ a study on the SSS examination practices in 6 leprosy control projects in Nigeria was undertaken to determine:

(a) the quality of smearing;

(b) the quality of reagents used for staining, appropriateness of the staining procedure and the accuracy of the staining;

(c) the accuracy of the microscopic reading, and

(d) other factors relevant to the improvement of the quality of SSS results (e.g. laboratory facilities, quality of control and job satisfaction for laboratory staff). 


\section{Methods}

At least 1 leprosy project from each of Nigeria's 4 primary Health Care zones (i.e. Zone A-Ogun and Bendel States; Zone B-Imo State; Zone C-Kaduna and Zone DGongola and Bauchi States) was chosen for the study.

In all, 3 approaches were used to assess the laboratory services for leprosy control operating in the centres participating in the study:

1 A brief questionnaire about SSS practices in each project, facilities available, quality control activities and constraints to efficient laboratory output, training and job satisfaction.

2 A sample of SSS from the laboratory unit of the All Africa Leprosy and Rehabilitation Training Centre (ALERT) was offered to serve as a set for test reading of the Bacteriological Indices (BI) by the laboratory technicians of these Nigerian programmes.

3 A request that a sample of slides from each of the centres, together with their BI readings, be sent to ALERT for quality control, comment and advice.

The quality control presented here is based largely on the criteria proposed by de Rijk et al. ${ }^{4}$

A copy of the filled-in quality control form, as received from ALERT, together with comments, on the form as well as on the questionnaire, was sent to each of the participating technicians and programme managers so as to enable them to identify their strong and weak areas.

\section{Results}

The study revealed that as at August 1990 only about $50 \%$ of the leprosy hospitals in Nigeria have the facilities and manpower for regular SSS examination. This information was obtained through personal communication with the programme managers of the Nigerian leprosy referral centres.

\section{QUESTIONNAIRE}

In most of the leprosy control projects studied, each laboratory technician prepares and examines an average of 3-7 slides per working day. There is no defined protocol on whom to smear, and when.

All but 2 of the 11 laboratory workers who answered the questionnaire earn less than \$500.00 monthly; they are not given any incentives, be it cash or kind, and feel that their contributions to the leprosy control services are not appreciated. Only 3 of the 11 respondents were taught the technique of SSS while in the medical laboratory school, and of those, 2 felt their exposure was too inadequate to be of any practical benefit. All the laboratories have at least 1 functioning microscope each and 4 of the six projects experience significant periodic shortages in laboratory reagents, water and electricity; 3 of the projects undertake, albeit irregularly, some form of quality control with laboratories in Amsterdam and Germany; 8 of the 11 respondents admit to being unhappy with their jobs. The main reasons advanced were: 
Table 1. Quality of smearing

\begin{tabular}{lccc}
\hline Project & $\begin{array}{c}\text { No. of smears } \\
\text { sent by individual } \\
\text { leprosy projects }\end{array}$ & $\begin{array}{c}\text { No. of smears judged } \\
\text { as being of good } \\
\text { quality }\end{array}$ & $\begin{array}{c}\text { Percentage of well- } \\
\text { smeared slides }\end{array}$ \\
\hline 01 & 24 & 0 & 0 \\
02 & 10 & 2 & 20 \\
03 & 24 & 4 & 17 \\
04 & 24 & 4 & 17 \\
05 & 14 & 2 & 14 \\
06 & 24 & 2 & 10 \\
07 & 20 & 16 & 12 (average) \\
Total & 140 & 2 & \\
\hline
\end{tabular}

(a) lack of 'recognition';

(b) slow career advancement;

(c) inadequacy of overseas training, compared to that obtained by leprosy control supervisors and doctors.

\section{QUALITY OF SMEARING}

Only $12 \%$ of SSS sent by the projects for assessment of smear quality were adjudged as being of good quality by the ALERT laboratory staff (Table 1). Reasons for the poor smear quality include too much blood in the smears and too little smear material on the slide.

\section{QUALITY OF STAINING}

Only $1 \%$ of slides sent by the projects for assessment of quality were considered to be properly stained (Table 2 ). It follows that poorly smeared slides are likely to be of poorly stained quality, but other reasons for poor staining included excessive granules on the stained smears (probably due to improperly filtered reagents) and overdecolourization during staining procedures.

Table 2. Quality of staining

\begin{tabular}{lccc}
\hline $\begin{array}{l}\text { No. of smears sent } \\
\text { code }\end{array}$ & $\begin{array}{c}\text { No. of smears judged } \\
\text { by individual leprosy } \\
\text { projects }\end{array}$ & $\begin{array}{c}\text { Percentage of } \\
\text { well-stained } \\
\text { slides }\end{array}$ \\
\hline 01 & 24 & 0 & 0 \\
02 & 10 & 0 & 0 \\
03 & 24 & 0 & 0 \\
04 & 24 & 0 & 0 \\
05 & 14 & 0 & 0 \\
06 & 24 & 2 & 0 \\
07 & 20 & 0 & 1 (average) \\
Total & 140 & 2 & \\
\hline
\end{tabular}


Table 3. BI readings (I)

\begin{tabular}{|c|c|c|c|}
\hline $\begin{array}{l}\text { Project } \\
\text { code }\end{array}$ & $\begin{array}{c}\text { No. of smears } \\
\text { sent to ALERT }\end{array}$ & $\begin{array}{l}\text { No. of smear } \\
\text { readings showing } \\
\text { good correlation } \\
(-1,0,+1)\end{array}$ & $\begin{array}{c}\text { Percentage of } \\
\text { smears showing } \\
\text { good correlation }\end{array}$ \\
\hline 01 & 24 & 0 & 0 \\
\hline 02 & 10 & 3 & 3 \\
\hline 03 & 24 & 18 & 75 \\
\hline 04 & 24 & 17 & 71 \\
\hline 05 & 14 & 14 & 100 \\
\hline 06 & 24 & 11 & 46 \\
\hline 07 & 20 & 19 & 95 \\
\hline Total & 140 & 82 & 59 (average) \\
\hline
\end{tabular}

\section{ACCURACY OF BI READINGS}

In assessing the accuracy of BI readings, a difference of \pm 1 was considered to be of little significance, and therefore acceptable. Thus a good correlation was assessed as the sum of the number of readings with differences $-1,0,+1$ taken as a percentage of the total number of smears assessed.

Using this criterion, only $59 \%$ of all the smears sent by individual projects to ALERT for assessment were found to show good correlation (Table 3). Similarly, using the above criterion, only $52 \%$ of the readings done in the Nigerian institutions on slides sent from ALERT showed good correlation (Table 4). This is much lower than the $80 \%$ correlation proposed by de Rijk et al. or the $95 \%$ correlation that is achieved by ALERT laboratory staff. $^{5}$

Table 4. BI readings (II)

\begin{tabular}{|c|c|c|c|}
\hline $\begin{array}{l}\text { Project } \\
\text { code }\end{array}$ & $\begin{array}{c}\text { ALERT } \\
\text { No. smears } \\
\text { examined for BI }\end{array}$ & $\begin{array}{l}\text { No. of smear } \\
\text { readings showing } \\
\text { good correlation } \\
(-1,0,+1)\end{array}$ & $\begin{array}{c}\text { Percentage of } \\
\text { smears showing } \\
\text { good correlation }\end{array}$ \\
\hline 01 & 24 & 0 & 0 \\
\hline 02 & 22 & 13 & 59 \\
\hline 03 & 20 & 12 & 60 \\
\hline 04 & 20 & 15 & 75 \\
\hline 05 & 24 & 19 & 79 \\
\hline 06 & 22 & 20 & 91 \\
\hline 07 & 20 & 0 & 0 \\
\hline Total & 152 & 79 & 52 (average) \\
\hline
\end{tabular}




\section{Discussion}

Bacteriological examination is very important and highly relevant to leprosy control, but the standards of SSS examination practices, especially in leprosy-endemic countries like Nigeria, is probably the weakest link in most leprosy control programmes. ${ }^{6,7}$

From the results, it is obvious that a lot needs to be done if the existing situation vis- $\grave{a}$ vis SSS practices in these projects is to be improved, and 2 approaches are recommended:

1. training;

ii. supervision and support for laboratory technicians.

\section{i. Training}

The National Tuberculosis and Leprosy control programme should, as a matter of policy, ensure that each States' leprosy referral hospital has a good laboratory and trained manpower.

The training of general laboratory technicians needs to be reviewed to include the taking, smearing and reading of smears. Because the treatment of leprosy has always operated as a 'special service' most schools of laboratory technology lack the access to patients needed for this training. While in the long term, the integration of leprosy into Primary Health Care is expected to correct this anomaly, a desirable short-term measure would be to arrange for trainee laboratory technicians and assistants to come and work for some weeks in laboratories involved in leprosy work.

Laboratory workers currently working in these leprosy hospitals would definitely benefit from refresher courses on the smearing, staining and reading of SSS. The laboratory department of ALERT has already indicated a willingness to (re)train these workers, either in Nigeria or at ALERT, in Ethiopia.

\section{ii. Supervision and support}

A system of quality control is desirable. In view of the low quality of SSS smear practices currently existing, it may be wise, in the short term, to organize periodic quality controls with reference laboratories in ALERT, Germany and the Netherlands, while aiming for the development of the laboratory service in at least 1 leprosy project in each Primary Health Care zone to that of a reference laboratory for the zone.

It is noteworthy that the feedback obtained so far from the participants reveals a high degree of stimulation and enthusiasm, and such positive feedbacks have been reported by other workers. ${ }^{8,9}$

It is hoped that experiences gained in quality control should stimulate further training and correct other factors that hinder the attainment of high quality SSS practices.

It is important that clear and uniform guidelines be given on:

1 whom to smear and when;

2 the technique of staining smears;

3 the technique of smearing and fixation. ${ }^{10}$

In view of the limited resources available for SSS practices, it may be necessary to give up the routine laboratory examination of PB patients so that more time can be spent on 
bacteriological examination of $\mathrm{MB}$ cases where it is actually needed to monitor response to chemotherapy. " Also, the morale of some of our technicians who, especially during periods of MDT implementation, are burdened with the examination of large numbers of negative smears, will be raised.

It is basic to management that managers should 'lead from the front', appreciating the skills and responsibilities of their staff, and they should care for and value their staff and understand their problems. Unfortunately, most leprosy programme managers have little or no experience in skin smear practices. They are therefore unable to adequately encourage, aid or advise their laboratory staff. ${ }^{10}$ The fact that this study reveals the frustration and demotivation of the laboratory staff shows that it would be wise for senior managers, whether medical or non-medical, to have laboratory and personnel management included in their training.

These factors require urgent attention if the existing unsatisfactory state of SSS practices operating in these Nigerian leprosy projects is to improve.

\section{Acknowledgements}

This inventory and assessment project was fully sponsored by the Netherland Leprosy Relief Association. I am also grateful to Dr A. J. de Rijk, Senior Field Research Medical Officer, ALERT and Mrs Gunilla Ganlöv, Head of Laboratory, ALERT, Ethiopia, for their moral and technical support.

\section{Ref erences}

1 WHO Bulletin. Vol. 70, 1992.

2 Jopling WH. Handbook of Leprosy, 3rd edn, London: Heineman, 1984, pp. 42.

3 WHO/CTD/LEP/91.3 MDT Questions aǹd Answers. Q 31.

4 de Rijk AJ, Nilson T, Chonde M. Quality control of skin smear practices in leprosy programmes, preliminary experiences with inter-observer comparison in routine services. Lepr Rev, 1985; 56: 177-91.

5 de Rijk AJ (1990) personal communication.

${ }^{6}$ Georgiev GD, McDougall AC. The bacteriological examination of slit skin smear in leprosy control programmes using multidrug therapy: a plea for radical changes in current operational methodology. Ind $J$ Lepr, 1987; 59: 373-85.

7 WHO Expert Committee on Leprosy. Sixth Report. Technical Report Series No. 768. WHO: Geneva, 1988, pp. 16-17.

${ }^{8}$ Vettam L, Pritze S. Reliability of skin smear results: experience with quality control of skin smears in different routine services in leprosy control programmes. Lepr Rev, 1989; 60: 187-79.

9 Vettam L, Pritze S. Experiences with repeated quality controls of skin smears in different routine services in leprosy control programmaes (letter). Lepr Rev, 1990; 61: 394-6.

10 ILEP Medical Bulletin: Improving skin smears and reading of the Bacteriological Index in MDT le prosy control programmes. Issue No. 3, December 1990.

11 Rao PS et al. Is bacteriological examination by skin smear necessary in all paucibacillary leprosy patients in mass control programmes? Lepr Rev, 1991; 62: 303-9. 
Inventaire de l'exécution des frottis de peau dans six programmes de contrôle de la peste au Nigéria

\section{NiYi AwOFESo \\ Résumé Une étude de l'exécution de examens de frottis de peau fendue (SSS) dans 6 programmes nigériens de contröle de la peste a été menée dans le but de juger la façon dont le frottis, la coloration et la lecture étaient exécutés. Les résultats ont indiqué que les techniques standards de SSS laissaient beaucoup à désirer. Il y a un besoin urgent de formation autant que de supervision et de soutien du personnel de laboratoire pour améliorer cette situation déplorable. \\ Inventorio de los métodos de frotis dérmico ("SSS") en seis programas para el control de la lepra en Nigeria}

\section{NiYi Awofeso}

Resumen Se realizó un estudio de los métodos de frotis dérmico (SSS) en 6 programas para el control de la lepra en Nigeria para evaluar la calidad de los métodos de frotis, coloración y lectura. Los resultados indican que la calidad de los métodos SSS usados son mucho menos que perfectos. Hay una gran necesidad para la capacitación además de supervisión y soporte del personal si se pretende mejorar esta situación deplorable. 